Hal 13 - 19

\title{
ANALISIS KEMAMPUAN BERPIKIR KRITIS SISWA LINTAS MINAT PADA PEMBELAJARAN BIOLOGI KELAS X IIS SMA NEGERI 11 KOTA JAMBI
}

\section{ANALYSIS OF CRITICAL THINKING SKILLS STUDENTS INTEREST CROSS IN LEARNING BIOLOGY CLASS X SMAN 11 JAMBI}

\author{
Eka Sulistiani ${ }^{1)}$ Retni S Budiarti ${ }^{2)}$ Muswita $^{3)}$ \\ ${ }^{2}$ Staf Pengajar Prodi Pendidikan Biologi Universitas Jambi \\ ${ }^{3}$ Staf Pengajar Prodi Pendidikan Biologi Universitas Jambi \\ ekasulistiani33@yahoo.com
}

\begin{abstract}
This study aims to determine students' critical thinking skills across an interest in learning biology class X IIS SMA 11 Jambi. The design of this research is descriptive research with quantitative and qualitative research methods. Sources of data in this research is observation sheet, self-assessment questionnaires and assessment questionnaires among students. The results showed the students' critical thinking abilities viewed from 5 critical aspects of forward- thinking that provide a simple explanation of $56.34 \%, 69.79 \%$ Developing basic skills, Summing up 63.66\%, 59.69\% providing further explanation, set the strategy and tactics $69,84 \%$. Based on the observation of the students' critical thinking skills that are in the interest of cross criterion was 7.5\%, and $92.5 \%$ higher. And based on self-assessment questionnaires, critical thinking ability of students is at a low $2.5 \%$ criterion, was $37.5 \%$, $32.5 \%$ high, very high $27.5 \%$. Based on the assessment questionnaire among students, students' thinking skills are the criteria were $70 \%, 20 \%$, very high $7.5 \%$ and $2.5 \%$ lower. This study concluded that the level of critical thinking skills of students cross an interest in learning biology class X IIS SMA 11 Jambi are on average medium and High criteria. Based on this study suggested needs teacher effort in improving students 'critical thinking by using the right strategies that can foster students' critical thinking skills.
\end{abstract}

Keywords: cross interest, critical thinking skills, learning biology.

ABSTRAK. Penelitian ini bertujuan untuk mengetahui kemampuan berpikir kritis siswa lintas minat pada pembelajaran Biologi kelas X IIS SMA Negeri 11 Kota Jambi. Rancangan penelitian ini adalah penelitian deskriptif dengan metode penelitian kuantitatif dan kualitatif. Sumber data dalam penelitian ini berupa lembar observasi, angket penilaian diri, dan angket penilaian antar peserta didik. Hasil penlitian menunjukkan kemampuan berpikir kritis siswa dilihat dari 5 aspek berpiki kritis yaitu: Memberikan penjelasan sederhana 56,34\%, Membangun keterampilan dasar 69,79\%, Menyimpulkan 63,66\%, Memberikan penjelasan lanjut 59,69\%, Mengatur strategi dan taktik 69,84\%. Berdasarkan observasi kemampuan berpikir kritis siswa lintas minat berada pada kriteria sedang 7,5\%, dan tinggi $92,5 \%$. Berdasarkan angket penilaian diri, kemampuan berpikir kritis siswa berada pada kriteria rendah 2,5\%, sedang 37,5\%, tinggi 32,5\%, dan sangat tinggi 27,5\%. Berdasarkan angket penilaian antar peserta didik, kemampuan berpikir siswa berada pada kriteria sedang $70 \%$, tinggi $20 \%$, sangat tinggi $7,5 \%$, dan rendah 2,5\%. Dari hasil penelitian dapat disimpulkan bahwa tingkat kemampuan berpikir kritis siswa lintas minat pada pembelajaran Biologi kelas $\mathrm{X}$ IIS SMA Negeri 11 Kota Jambi berada pada rata-rata kriteria sedang dan tinggi. Berdasarkan penelitian ini disarankan perlu upaya guru dalam meningkatkan berpikir kritis siswa dengan cara menggunakan strategi yang tepat yang dapat menumbuhkan kemampuan berpikir kritis siswa.

Kata kunci : lintas minat, kemampuan berpikir kritis, pembelajaran biologi. 


\section{PENDAHULUAN}

Dalam Kurikulum 2013, peserta didik yang memiliki kemampuan akademik di atas peserta didik lain diberi kesempatan untuk mendalami matapelajaran-matapelajaran pada kelompok peminatannya. Hal ini memberi kesempatan bagi peserta didik yang pada mata pelajaran tertentu di kelompok peminatannya memiliki kemampuan dan prestasi tertentu sehingga penguasaan terhadap substansi matapelajaran bersangkutan menjadi tumpuan bagi kelangsungan pendidikan pada jenjang yang lebih tinggi (Anonim, 2013:8).

Anonim (2013:8) juga menjelaskan agar bakat, minat, dan kemampuan peserta didik terlayani maka salah satu kebijakan penting dalam Kurikulum 2013 adalah memberi kesempatan kepada peserta didik untuk memilih kelompok mata pelajaran (peminatan) yang diminati. Pemilihan kelompok matapelajaran tersebut dipilih peserta didik semenjak masuk ke SMA atau kelas $\mathrm{X}$ semester pertama, peserta didik boleh memilih kelompok matapelajaran, yakni peminatan Ilmu Pengetahuan Alam, Ilmu-ilmu Sosial, atau Ilmu Bahasa dan Budaya.

Pada hakikatnya IPA dibangun atas dasar produk ilmiah, proses ilmiah dan sikap siswa. IPA dipandang pula sebagai proses, sebagai produk, dan sebagai prosedur. Sebagai proses diartikan semua kegiatan ilmiah untuk menyempurnakan pengetahuan tentang alam maupun untuk menemukan pegetahuan baru. Sebagai produk diartikan sebagai hasil proses, berupa pegetahuan yang diajarkan dalam sekolah atau di luar sekolah atau bahan bacaan untuk penyebaran atau dissiminasi pengetahuan. Sebagai prosedur dimaksudkan adalah metodologi atau cara yang dipakai umtuk mengetahui sesuatu yang lazim disebut metode ilmiah (scientifik method) (Trianto, 2010:137). Menyikapi hal tersebut, Susanto
(2013:126) menjelaskan bahwa keterampilan berpikir kritis perlu dikembangkan dalam diri siswa karena melalui keterampilan berpikir kritis, siswa dapat lebih mudah memahami konsep, peka akan masalah yang terjadi sehingga dapat memahami dan menyelesaikan masalah, dan mengaplikasikan konsep dalam situasi yang berbeda. Pendidikan perlu mengembangkan peserta didik agar memiliki kemampuan bersikap dan berperilaku adaptif dalam menghadapi tentangan dan tuntutan dalam kehidupan sehari-hari secara aktif.

Berpikir kritis membantu siswa mempelajari bidang ilmu tertentu dengan perspektif yang lebih terfokus. Berpikir kritis akan memudahkan siswa memahami bidang ilmu tertentu secara lebih mendalam sehingga tidak percaya begitu saja pada apa yang dipaparkan. Siswa akan berusaha mencari informasi secara lebih mendalam dan lengkap serta mengevaluasi konsistensi logis dari pemikiran-pemikiran yang disajikan (Surya, 2012:170-171).

Berdasarkan observasi kegiatan pembelajaran biologi pada kelas minat di SMA Negeri 11 Kota Jambi, pada saat proses pembelajaran berlangsung terlihat kemampuan berpikir kritis siswa lintas minat pada saat proses pembelajaran. berdasarkan hal tersebut, peneliti tertarik untuk mengadakan penelitian lebih lanjut dengan judul: "Analisis Kemampuan Berpikir Kritis Siswa Lintas Minat pada Pembelajaran Biologi Kelas X IIS SMA Negeri 11 Kota Jambi"

\section{METODE}

\section{Rancangan Penelitian}

Rancangan penelitian ini adalah penelitian deskriptif dengan metode penelitian kuantitatif dan kualitatif. Sebagaimana dikemukakan oleh Arikunto (2010:3) penelitian deskriptif adalah penelitian yang bertujuan untuk mengumpulkan informasi mengenai 
status gejala yang ada, yaitu keadaan gejala menurut apa adanya pada saat penelitian dilakukan, sehingga dapat menggambarkan keadaan subjek pada saat itu atau menggambarkan keadaan lapangan.

\section{Instrumen Penelitian}

Instrumen penelitian yang digunakan dalam pengumpulan data adalah lembar observasi, angket penilaian diri, dan angket penilaian antar peserta didik.

\section{Jenis Data}

Jenis data yang dikumpulkan dalam penelitian ini yaitu data kuantitatif dan kualitatif. Sumber data dalam penelitian ini adalah data primer dan data sekunder. Data primer diperoleh langsung dari observasi selama proses pembelajaran. Data sekunder diperoleh penulis melalui jawaban angket penilaian diri dan angket penilain peserta didik.

Instrumen observasi berisi butir pernyataan yang akan dijawab oleh peneliti sendiri sesuai dengan kenyataan yang sebenarnya menggunakan skala guttman. Angket berisi butir pernyataan yang akan dijawab oleh siswa-siswi sesuai dengan kenyataan yang sebenarnya dengan menggunakan skala likert 1-4, dengan rating scale.

\section{Analisis Data}

\section{Analisis Observasi}

Lembar observasi sikap belajar biologi dianalisis menggunakan persentase dengan mengunakan rumus Sudijono (2012:43) sebagai berikut:

Keterangan:

$$
P=\frac{F}{N} \times 100 \%
$$

$\mathrm{P}=$ Persentase analisis sikap berpikir kritis siswa lintas minat

$\mathrm{F} \quad=$ Skor jawaban responden

$\mathrm{N} \quad=$ Skor total

Kategori pengukuran (penafsiran) angket sebagai berikut (Riduwan, 2012b:41):
Tabel 3.5 Kriteria Penafsiran Angket

\begin{tabular}{|c|c|c|}
\hline No & Persentase $(\%)$ & Kategori \\
\hline 1 & $81-100$ & Sangat Tinggi \\
\hline 2 & $61-80$ & Tinggi \\
\hline 3 & $41-60$ & Sedang \\
\hline 4 & $21-40$ & Rendah \\
\hline 5 & $0-20$ & Sangat Rendah \\
\hline
\end{tabular}

\section{Analisis Angket}

Sikap berpikir kritis siswa dalam pembelajaran biologi pada siswa lintas minat kelas X IIS SMA Negeri 11 Kota Jambi pada saat mengikuti pelajaran biologi yang diukur dengan skala Gutman dianalisis menggunakan skala Likert dianalisis dengan teknik persentase. Persentase ini digunakan untuk mendapatkan data sebagaimana adanya tentang objek yang diteliti. Analisis data angket digunakan rumus yang dimodifikasi dari Sudijono (2012:43) sebagai berikut:

$$
P=\frac{F}{N} \times 100 \%
$$

Keterangan:

$\mathrm{P}=$ Persentase analisis sikap berpikir kritis siswa lintas minat

$\mathrm{F}=$ Skor jawaban responden

$\mathrm{N}=$ Skor total

Kategori pengukuran (penafsiran) angket sebagai berikut (Riduwan, 2012b:41):

Tabel 3.6 Kriteria Penafsiran Angket

\begin{tabular}{|c|c|c|}
\hline No & Persentase $(\%)$ & Kategori \\
\hline 1 & $81-100$ & Sangat Tinggi \\
\hline 2 & $61-80$ & Tinggi \\
\hline 3 & $41-60$ & Sedang \\
\hline 4 & $21-40$ & Rendah \\
\hline 5 & $0-20$ & Sangat Rendah \\
\hline
\end{tabular}

\section{Tempat dan Waktu Penelitian}

Penelitian ini dilaksanakan di SMA Negeri 11 Kota Jambi di kelas X IIS pada semester ganjil tahun ajaran 2014/2015. 


\section{HASIL DAN PEMBAHASAN}

\section{Hasil Observasi Kemampuan Berpikir Kritis Siswa}

Data observasi dilakukan dengan menggunakan instrumen yang telah divalidasi oleh Validator. Instrumen digunakan untuk melihat kemampuan berpikir kritis siswa lintas minat pada saat proses pembelajaran biologi. Dari observasi yang telah dilakukan didapat data sebagai berikut:

Tabel 4.1 Distribusi Lembar Observasi Kemampuan Berpikir Kritis Siswa Lintas Minat pada Pembelajaran Biologi Kelas X IIS SMA Negeri 11 Kota Jambi

\begin{tabular}{|c|c|c|c|}
\hline No. & $\begin{array}{c}\text { Kriteria } \\
\text { Kemampuan } \\
\text { Berpikir Kritis }\end{array}$ & $\begin{array}{c}\text { Frekuensi } \\
(\mathrm{F})\end{array}$ & Persentase \\
\hline 1 & Sangat Tinggi & 0 & 0 \\
\hline 2 & Tinggi & 37 & 92,5 \\
\hline 3 & Sedang & 3 & 7,5 \\
\hline 4 & Rendah & 0 & 0 \\
\hline 5 & Sangat Rendah & 0 & 0 \\
\hline \multicolumn{2}{|c|}{ Jumlah } & 40 & 100 \\
\hline
\end{tabular}

Tabel 4.1 menunjukkan bahwa 37 responden dengan persentase $92,5 \%$ memiliki kemampuan berpikir kritis pada pembelajaran biologi dengan kategori tinggi. Selanjutnya, 3 responden dengan persentase $\quad 7,5 \% \quad$ memiliki kemampuanberpikir kritis dengan kategori sedang. Dari hasil observasi ini,dapat dikatakan bahwa kemampuan berpikir kristis siswa lintas minat pada pembelajaran biologi dikatakan tinggi.

\section{Hasil Angket Penilaian Diri}

Salah satu instrumen yang digunakan dalam penelitian ini adalah angket. Angket diberikan kepada 40 siswa kelas X IIS di SMA Negeri 11 Kota Jambi setelah pembelajaran berlangsung. Melaluiangket yang diberikan kepada 40 responden ada12 item pernyataan yang diajukan. Data kemampuan berpikir kritis siswa lintas minat pada pembelajaran biologi dikelas X IIS SMA Negeri 11
Kota Jambi dilihat dari angket penilaian diri dapat dilihat sebagi berikut:

Tabel 4.3 Distribusi Angket Penilaian Diri untuk Melihat Kemampuan Berpikir Kritis Siswa Lintas Minat pada Pembelajaran Biologi Di Kelas X IIS SMA Negeri Kota Jambi

\begin{tabular}{|c|c|c|c|}
\hline No. & $\begin{array}{c}\text { Kriteria } \\
\text { Kemampuan } \\
\text { Berpikir Kritis }\end{array}$ & $\begin{array}{c}\text { Frekuensi } \\
(\mathrm{F})\end{array}$ & Persentase \\
\hline 1 & Sangat Tinggi & 11 & 27,5 \\
\hline 2 & Tinggi & 13 & 32,5 \\
\hline 3 & Sedang & 15 & 37,5 \\
\hline 4 & Rendah & 1 & 2,5 \\
\hline 5 & Sangat Rendah & 0 & 0 \\
\hline \multicolumn{2}{|c|}{ Jumlah } & 40 & 100 \\
\hline
\end{tabular}

\section{Hasil Angket Penilaian antar Peserta Didik}

Instrumen angket kedua yang diberikan kepada siswa dalam penelitian ini adalah angket penilaian antar peserta didik. Angket terdiri atas 12 item pernyataan yang diajukan untuk menilai teman lainnya. Angket diberikan kepada 40 siswa kelas X IIS di SMA Negeri 11 Kota Jambi setelah pembelajaran berlangsung. Data kemampuan berpikir kritis siswa lintas minat pada pembelajaran biologi dikelas X IIS SMA Negeri 11 Kota Jambi dilihat dari angket penilaian antar peserta didik dapat dilihat sebagi berikut:

Tabel 4.5 Distribusi Angket Penilaian Antar Peserta Didik untuk Melihat Kemampuan Berpikir Kritis Siswa Lintas Minat pada Pembelajaran Biologi Di Kelas X IIS SMA Negeri Kota Jambi

\begin{tabular}{|c|c|c|c|}
\hline No. & $\begin{array}{c}\text { Kriteria } \\
\text { Kemampuan } \\
\text { Berpikir } \\
\text { Kritis }\end{array}$ & $\begin{array}{c}\text { Frekuensi } \\
(\mathrm{F})\end{array}$ & Persentase \\
\hline 1 & $\begin{array}{c}\text { Sangat } \\
\text { Tinggi }\end{array}$ & 3 & 7,5 \\
\hline 2 & Tinggi & 8 & 20 \\
\hline 3 & Sedang & 28 & 70 \\
\hline 4 & Rendah & 1 & 2,5 \\
\hline 5 & $\begin{array}{c}\text { Sangat } \\
\text { Rendah }\end{array}$ & 0 & 0 \\
\hline \multicolumn{2}{|c|}{ Jumlah } & 40 & 100 \\
\hline
\end{tabular}




\section{PEMBAHASAN}

Proses pembelajaran yang selama ini dilakukan secara konseptual dapat dikembangkan untuk lebih menekankan pada peningkatan dan menunbuhkan kemempuan siswa dalam berpikir kritis yang sesuai dengan perkembangan usianya. Menurut Susanto (2013:127), keterampilan berpikir kritis perlu dikembangkan dalam diri siswa karena melalui berpikir kritis, siswa dapat lebih mudah memahami konsep, peka akan masalah yang terjadi sehingga dapat memahami dan menyelesaikan masalah, serta mampu mengaplikasikan konsep dalam situasi yang berbeda. Selanjutnya Surya (2012:169) menjelaskan bahwa berpikir kritis penting karena memungkinkan seseorang untuk menganalasis, menilai, menjelaskan, dan merestrukturisasi pemikirannya sehingga dapat memperkecil resiko untuk mengadopsi keyakinan yang salah, maupun berpikir dan bertindak dengan menggunakan keyakinan yang salah tersebut.

Berdasarkan hasil analisis data penelitian, menunjukkan bahwa sebagian besar siswa kelas X IIS SMA Negeri 11 Kota Jambi memiliki kemampuan dalam berpikir kritis dalam proses pembelajaran, dengan tingkat kemampuan berada pada kriteria tinggi dan sedang. Tingginya tingkat kemampuan ini dominan terjadi pada aspek kemampuan (1) memberikan penjelasan sederhana, (2) membangun keterampilan dasar, (3) Menyimpulkan, (4) memberikan penjelasan lanjut, (5) mengatur strategi dan taktik. Adapun uraian deskriptif kemampuan guru siswa dalam memunculkan setiap aspek berpikir kritis pada pelaksanaan pembelajaran biologi di SMA Negeri 11Kota Jambi sebagai berikut:

\section{Memberikan Sederhana}

Kemampuan

Penjelasan

memberikan penjelasan sederhana berkaitan dengan bagimana siswa mampu mendefinisikan apa yang diketahui maupun tidak dengan cara bertanya maupun menjawab suatu penjelasan maupun tantangan. Hal ini akan menciptakan interaksi langsung antara guru dan siswa sehingga pembelajaran berlangsung interaktif. Susanto (2013:128) menjelaskan bahwa dalam pengembangan kemampuan berpikir kritis siswa, hakikat pembelajaran yang dilakukan guru berarti interaksi langsung antara guru dan siswa. Selanjutnya Susanto (2013:126) menyatakan bahwa agar pembelajaran dapat interaktif, maka desain pembelajaran harus menarik sehingga siswa dapat terlibat aktif dalam proses pembelajaran.dalam pembelajaran yang mengembangkan keterampilan berpikir kritis lebih melibatkan siswa sebagai pemikir, bukan seorang yang diajar.

Hasil analisis data observasi menunjukkan bahwa kemampuan siswa dalam memberikan penjelasan sederhana $56,34 \%$ dengan kategori sedang. Hal ini menunjukkan perlunya usaha guru untuk meningkatkan kemampuan siswa dalam memberikan penjelasan sederhana. Untuk itu, Susanto (2013:127) menjelaskan bahwa untuk dapat menumbuhkan berpikir kritis siswa dapat diterapkan suatu bentuk latihan-latihan yang mengacu pada pola pikir siswa.

Berdasarkan pengamatan selama proses pembelajaran, guru telah mampu memancing siswa untuk dapat bertanya maupun menjawab dengan cara memberikan masalah yang ada di lingkungan siswa. Sehingga permasalah yang diberikan bersifat kontekstual dan dekat dengan kehidupan sehari-hari siswa dengan harapan siswa lebih mudah memahami isi pembelajaran. Hal ini sudah sesuai dengan pengimplementasian kurikulum menurut Mulyasa (2013:106), dalam rangka menyukseskan implementasi kurikulum 2013 perlu didayagunakan lingkungan sebagai sumber belajar secara optimal. Untuk kepentingan tersebut para guru, fasilitator dituntut untuk mendayagunakan 
lingkungan, baik lingkungan fisik maupun lingkungan sosial, serta menjalin kerjasama dengan unsur-unsur terkait yang dipandang dapat menunjang upaya pengembangan mutu dan kualitas pembelajaran.

\section{Membangun Keterampilan Dasar}

Kemampuan membangun keterampilan dasar dalam hal ini merupakan kemampuan siswa dalam memertimbangkan sumber yang dapat dipercaya, mengamati dan mempertimbangkan suatu laporan hasil observasi. Menurut Surya (2012:185), keterampilan ini menuntut pemikiran yang matang dalam menentukan nilai suatu materi, metode, informasi maupun pendapat untuk maksud tertentu atau kesanggupan memberikan pertimbangan berdasarkan kriteria yang dipakai.

Berdasarkan pengamatan yang dilakukan pada proses pembelajaran dapat dilihat bahwa siswa sudah mampu untuk melaporkan hasil observasi serta menggunakan bukti-bukti pendukung dalam memprentasikan hasil observasi. Hal ini didukung oleh hasil analisis data observasi yang menunjukkan kemampuan siswa membangun keterampilan dasar dengan persentase $69,79 \%$ dengan kategori tinggi.

\section{Menyimpulkan}

yaitu kemampuan untuk menarik interpretasi (menafsirkan) hasi-hasil analisis data, fakta, dan logika berupa temuan baru maupun ungkapan menyeluruh dari hasil analisis data yang berfungsi sebagai informan objektif dan pendapat yang teruji tentang jawaban dari pokok permasalahan (Surya, 2013:184). Kemampuan siswa kelas X IIS dalam menyimpulkan termasuk dalam kategori tinggi yakni dengan persentase $63,66 \%$. Hal ini terkait dengan kemampuan siswa dalam mengemukakan simpulan dan hipotesis berdasarkan fakta-fakta yang ada yang didapat siswa. Siswa mampu menguraikan setiap data yang didapat dan mempresentasikannya di depan kelas.

Lebih luas Surya (2012:162)

menjelaskan bahwa berpikir kritis meliputi kemampuan untuk menarik kesimpulan dan generalisasi yang bisa dipertanggungjawabkan, menguji kesimpulan dan generalisasi yang dibuat, merekonstruksi pola keyakinan yang dimiliki berdasarkan pengalaman yang lebih luas dan melakukan pertimbangan yang akurat.

\section{Memberikan Penjelasan Lanjut}

Kemampuan siswa dalam memberikan penjelasan lanjut dalam hal ini berupa kemampuan untuk membuat suatu definisi maupun berargumen. Surya (2012:163) menjelaskan bahwa argumen merupakan pernyataan yang dilandasi oleh data-data. Namun secara umum argumen dapat diartikan sebagai alasan yang dapat dipakai untuk memperkuat atau menolak suatu pendapat, pendirian, atau gagasan.

Berdasarkan pengamatan yang dilakukan, telah tampak kemampuan siswa untuk memberikan suatu penjelasan berupa argumen-argumen, baik menanggapi hasil observasi maupun isi laporan yang telah dikemukakan. Hasil analisis data menunjukkan kemampuan siswa dalam memberikan suatu penjelasan dalam kategori sedang. Hasil ini dimungkinkan karena ketidakbiasaan siswa dalam beragumen menggunakan data-data yang sifatnya real yang didapat selama proses pembelajaran. Kelas X IIS lebih terbiasa pada data-data yang sifatnya sosial.

\section{Mengatur Strategi dan Taktik}

Kemampuan mengatur startegi dan taktik meliputi kemampuan menentukan tindakan dan berinteraksi dengan orang lain. Berdasarkan pengamatan yang telah dilakukan terlihat bahwa siswa kelas X IIS telah mampu menentukan tindakan, dalam hal ini contohnya siswa mampu menentukan 
langkah atau prosedur dalam melakukan observasi, serta membuat laporan percobaan. Dalam kegiatan proses pembelajaran, siswa juga telah mampu berinteraksi dengan teman lain selama proses pembelajaran. Hasil analisis data menunjukkan kemampuan siswa dalam mengatur strategi dan taktik dalam kategori tinggi dengan persentase $69,84 \%$.

Berdasarkan uraian di atas, sekiranya guru perlu menumbuhkan kemampuan berpikir kritis siswa dalam proses pembelajaran. Sesuai dengan pendapat Susanto (2013:127) yang menyatakan bahwa upaya untuk menumbuhkan kemampuan berpikir kritsis siswa merupakan suatu kewajiban yang harus dilakukan guru.dalam proses pembelajaran guru harus dapat melahirkan cara berpikir yang lebih kritis pada siswa. Guru dapat memberikan kesempatan dan dukungan kepada siswa untuk dapat menumbuhkan kemampuan berpikir kritisnya dengan memberikan metode pembelajaran yang sesuai diharapkan dapat membantu siswa menumbuhkan pengetahuan keterampilan nalar yang nantinya dapat berpengaruh pada kemampuan untuk berpikir kritis.

\section{SIMPULAN}

\section{Kesimpulan}

Berdasarkan hasil penelitian yang didapatkan, dapat disimpulkan bahwa tingkat kemampuan berpikir kritis siswa lintas minat pada pembelajaran Biologi kelas X IIS SMA Negeri 11 Kota Jambi berada pada rata-rata kriteria sedang dan tinggi. Hal ini dapat dilihat dari perolehan persentase hasil observasi berada pada kriteria sedang $(7,5 \%)$, dan tinggi $(92,5 \%)$. Serta berdasarkan angket penilaian diri, kemampuan berpikir kritis siswa berada pada kriteria rendah $(2,5 \%)$, sedang $(37,5 \%)$, tinggi $(32,5 \%)$, sangat tinggi $(27,5 \%)$. Berdasarkan angket penilaian antar peserta didik, kemampuan berpikir siswa berada pada kriteria sedang $(70 \%)$, tinggi (20\%), sangat tinggi $(7,5 \%)$, dan rendah $(2,5 \%)$.

\section{Saran}

Kemampuan siswa lintas minat dalam berpikir kritis belum seluruhnya tampak dalam proses pembelajaran, untuk itu perlu upaya guru dalam meningkatkan berpikir kritis siswa dengan cara menggunakan strategi yang tepat yang dapat menumbuhkan kemampuan berpikir kritis siswa.

\section{DAFTAR RUJUKAN}

Anonim. 2013. Model penyelenggaraan peminatan di SMA Tahun 2014. Jakarta: Kementerian Pendidikan dan Kebudayaan, Direktorat Jenderal Pendidikan Menengah.

Arikunto. S. 2010. Dasar-dasar Evaluasi Pendidikan. Jakarta:Bumi Aksara

Mulyasa. E. 2013. Pengembangan dan Implementasi Kurikulum 2013. Jakarta: Remaja Rosdakarya

Riduwan. 2012b. Dasar-Dasar Statistika. Bandung: Alfabeta

Sudijono.A. 2012. Pengantar Statistik Pendidikan. Jakarta: Raja Grafindo Persada

Surya. H. 2013. Cara Belajar Orang Jenius. Jakarta: Elex Media Komputindo

Susanto. A. 2013.Teori Belajar dan Pembelajaran di Sekolah Dasar. Jakarta:Kencana

Trianto. 2009. Mendesain Model Pembelajaran Inovatif Progresif. Jakarta: Kencana Prenada Media. 